\title{
Relapsing Tubulointerstitial Nephritis with Antimitochondrial M2 Antibody Accompanied by Pulmonary Involvement
}

\author{
Aya Nakamori, Fuyuko Akagaki, Yoshito Yamaguchi and Toshihiro Sugiura
}

\begin{abstract}
:
We herein report a 50-year-old woman who suffered from tubulointerstitial nephritis with antimitochondrial M2 antibody, distal renal tubular acidosis, and Fanconi syndrome. Our case also had interstitial pneumonia. After initially successful glucocorticoid therapy, tubulointerstitial nephritis and interstitial pneumonia relapsed. After the second successful round of glucocorticoid therapy, tubulointerstitial nephritis relapsed again and responded to glucocorticoid and azathioprine. This case might indicate (1) the association between pulmonary involvement and tubulointerstitial nephritis with antimitochondrial antibodies and (2) the need for a maintenance dose of glucocorticoid and immunosuppressants in tubulointerstitial nephritis with antimitochondrial antibodies.
\end{abstract}

Key words: tubulointerstitial nephritis, antimitochondrial antibodies, pulmonary involvement, immunosuppressant, distal renal tubular acidosis, Fanconi syndrome

(Intern Med 59: 1179-1187, 2020)

(DOI: 10.2169/internalmedicine.4048-19)

\section{Introduction}

The first case of tubulointerstitial nephritis (TIN) with primary biliary cholangitis (PBC) was reported in 1987 (1). Since then, cases of TIN with PBC and/or antimitochondrial antibodies (AMAs) have been reported to have similar clinical features of appearing predominantly in women, high serum IgM levels, AMA positivity, distal renal tubular acidosis, proximal renal tubular dysfunction, and responsiveness to glucocorticoid therapy (1-5).

However, some of those cases relapsed after glucocorticoid withdrawal or did not respond to glucocorticoids at all $(1,2)$. The standard therapy of TIN with AMAs has not been established yet. While TIN with AMAs can be complicated with other systematic diseases, such as Sjögren's syndrome (4), pulmonary involvement per se has not received much attention in TIN with AMAs.

\section{Case Report}

A 50-year-old woman was referred to the Department of Nephrology and Pulmonology in our hospital because of proteinuria and abnormal chest X-ray findings. She suffered from bone pain and dry cough. She had undergone fiberoptic bronchoscopy at another hospital about eight years earlier, but the findings were not specific, although we did not have an opportunity to obtain the results in detail. She had none of the following: dyspnea, fine crackles, skeletal deformities, chronic diarrhea, growth retardation, and Raynaud's phenomenon. She had a 2.5-pack-year history of smoking and had quit smoking 10 years ago. She consumed a modest amount of alcohol occasionally. She had no history of radiation exposure, other fume/dust inhalation, drug abuse, being exposed to heavy metals, or recent medication. She had no family history of kidney disease, but one of her grandfathers had had diabetes mellitus. Her height was $149.7 \mathrm{~cm}$, and she weighed $42.3 \mathrm{~kg}$. Her blood pressure was $104 / 70 \mathrm{mmHg}$. 


\section{Kidney disease}

The initial bloodwork findings were as follows: estimated glomerular filtration rate (eGFR) $57.2 \mathrm{~mL} / \mathrm{min} / 1.73 \mathrm{~m}^{2}$, urine protein $1.4 \mathrm{~g} / \mathrm{gCr}$, urine $\beta 2$ microglobulin (U- $\beta 2 \mathrm{MG}$ ) $14,774 \mu \mathrm{g} / \mathrm{L}$, urine $\mathrm{pH} 7.5$, positive urinary anion gap (34 $\mathrm{mEq} / \mathrm{L}$ ), high fractional excretion of uric acid (FEUA) (34.1\%), high fractional excretion of potassium (FEK) (12.0\%), normoglycemic glycosuria. An arterial blood gas analysis revealed metabolic acidosis $\left(\mathrm{pH} 7.323, \mathrm{HCO}_{3}{ }^{-} 19.6\right.$ $\mathrm{mEq} / \mathrm{L})$ with a normal anion gap $(9.4 \mathrm{mEq} / \mathrm{L})$ (Table). Computed tomography (CT) showed left kidney stones (Fig. 1a).

A histological analysis of the kidney showed 12 glomeruli, 7 of which had global sclerosis. Lymphocytes and CD 138-positive plasma cells had infiltrated into the interstitial compartment and between tubules. No other specific changes, such as mesangial cell proliferation, mesangial matrix expansion, or double contour, were evident (Fig. 2). IgG- and IgM-positive cells were not detected by the immunoenzyme method with formalin-fixed paraffin-embedded sections (Fig. 3). An immunofluorescence analysis showed no deposits of $\mathrm{IgG}, \operatorname{IgA}, \operatorname{IgM}, \mathrm{C} 3, \mathrm{C} 4$, or fibrinogen using fresh-frozen sections. Electron microscopy showed no basement membrane changes, dense deposits, fibrils, or mitochondrial alteration.

\section{Pulmonary involvement}

Arterial partial pressure oxygen $\left(\mathrm{PO}_{2}\right)$ was $69.6 \mathrm{mmHg}$. Carbon dioxide partial pressure $\left(\mathrm{PCO}_{2}\right)$ was $39.0 \mathrm{mmHg}$, which was higher than expected (about $35 \mathrm{mmHg}$ ). Incomplete respiratory compensation indicated that she also had respiratory acidosis with a wide alveolar-arterial oxygen difference $\left(\mathrm{A}-\mathrm{aDO}_{2}\right)$ (31.4 mmHg). CT showed bilateral multifocal consolidations (Fig. 1b-d). Fiberoptic bronchoscopy was not performed a second time for the histopathological analysis of the lung, at her request.

\section{Other results}

The IgM level was high $(630 \mathrm{mg} / \mathrm{dL})$, and the alkaline phosphatase (ALP) level was 725 IU/L. The bone mineral density at the distal forearm was $0.294 \mathrm{~g} / \mathrm{cm}^{2}$; the young adult mean was $61 \%$. Both SS-A and SS-B were negative. While the Rose Bengal tests and Schirmer's tests in both eyes were positive, she did not have any other ophthalmologic disorders. Neither a lip biopsy nor salivary gland scintigraphy showed any apparent abnormalities. She did not meet the diagnostic criteria of Sjögren's syndrome (6-8).

Given the above, she was diagnosed with TIN, distal renal tubular acidosis (RTA), Fanconi syndrome, and interstitial pneumonia at this time. Both osteomalacia and osteoporosis were suspected, although a bone biopsy and bone scintigraphy were not performed.

\section{Clinical course}

Oral prednisolone therapy (30 mg/day) was initiated with alendronate sodium hydrate. Her acidosis was adjusted with oral sodium bicarbonate. After several months, her eGFR had increased to $84.2 \mathrm{~mL} / \mathrm{min} / 1.73 \mathrm{~m}^{2}$, her serum phosphorus had increased to $3.4 \mathrm{mg} / \mathrm{dL}$, her ALP had decreased to $112 \mathrm{IU} / \mathrm{L}$, her U- $\beta 2 \mathrm{MG}$ had decreased to $9,305 \mu \mathrm{g} / \mathrm{L}$, and her IgM had decreased to $235 \mathrm{mg} / \mathrm{dL}$ (Fig. 4). Both the bone pain and dry cough were relieved. The bilateral multifocal pulmonary shadows had almost vanished (Fig. 1e). The dose of prednisolone was gradually reduced, and prednisolone administration ended after about 1.5 years.

However, gradually, she developed hypokalemia (3.1 $\mathrm{mEq} / \mathrm{L}$ ), so she started to take potassium L-aspartate. Her eGFR decreased to $31.7 \mathrm{~mL} / \mathrm{min} / 1.73 \mathrm{~m}^{2}$, serum phosphorus decreased to $1.1 \mathrm{mg} / \mathrm{dL}$, ALP increased to $356 \mathrm{IU} / \mathrm{L}$, and U$\beta 2 \mathrm{MG}$ increased to $61,513 \mu \mathrm{g} / \mathrm{L}$ with a high C-reactive protein (CRP) level $(6.17 \mathrm{mg} / \mathrm{dL})$. She also had to start potassium citrate-sodium citrate dehydrate to ameliorate her acidosis. She came to suffer bone pain and dry cough again, along with a fever. Chest CT showed bilateral lung infiltrates (Fig. 5a-c). The second round of oral prednisolone therapy (20 mg/day) was started about 3.5 years after the end of the first round. After a couple of weeks, her eGFR increased to $49.7 \mathrm{~mL} / \mathrm{min} / 1.73 \mathrm{~m}^{2}$ her serum phosphorus increased to $3.3 \mathrm{mg} / \mathrm{dL}$, her ALP decreased to $181 \mathrm{IU} / \mathrm{L}$, her U- $\beta 2 M G$ decreased to $19,336 \mu \mathrm{g} / \mathrm{L}$ (Fig. 4), and her CRP returned to $0.03 \mathrm{mg} / \mathrm{dL}$. The bilateral pulmonary infiltrates almost disappeared (Fig. 5d). Her bone pain, dry cough, and fever were ameliorated. The dose of prednisolone was gradually tapered, and the prednisolone therapy was halted after about four months due to concerns of glucocorticoidinduced osteoporosis.

Again, her eGFR eventually decreased to $27.3 \mathrm{~mL} / \mathrm{min} /$ $1.73 \mathrm{~m}^{2}$ and her serum phosphorus level to $1.9 \mathrm{mg} / \mathrm{dL}$. After starting oral alfacalcidol, the phosphorus level increased slightly to $2.5 \mathrm{mg} / \mathrm{dL}$ before gradually declining again to 1.6 $\mathrm{mg} / \mathrm{dL}$. The percent tubular re-absorption of phosphate (TRP) was $43.4 \%$, and the tubular maximum of phosphate (TmP/GFR) was $0.95 \mathrm{mg} / \mathrm{dL}$. The ALP level increased to $673 \mathrm{IU} / \mathrm{L}$, the U- $\beta 2 \mathrm{MG}$ level to $64,978 \mu \mathrm{g} / \mathrm{L}$, and the urine protein level to $2.6 \mathrm{~g} / \mathrm{gCr}$. She had to take more sodium bicarbonate and more potassium citrate-sodium citrate dihydrate to resolve her metabolic acidosis. The total amount of alkali consumed reached $2.3 \mathrm{mmol} / \mathrm{kg} / \mathrm{day}$, which was more than the amount required to treat distal RTA in adults (9).

After adjusting her metabolic acidosis by the oral administration of sodium bicarbonate for 2 weeks, the fractional excretion of bicarbonate was $8.0 \%$, which was considered sufficient for the diagnosis of a less severe type of proximal RTA (10). With alkali supplementation, she required more potassium L-aspartate supplementation $(18.0 \mathrm{mEq} /$ day $)$ to avoid further hypokalemia (serum potassium $3.3 \mathrm{mEq} / \mathrm{L}$ ). The urine $\mathrm{pH}$ was 8.5 with a positive urinary anion gap (88.2 $\mathrm{mEq} / \mathrm{L})$, high FEUA (75.6\%), high FEK (105.1\%), and normoglycemic glycosuria (casual blood glucose $93 \mathrm{mg}$ / dL, hemoglobin A1c 5.4\%, urine sugar 696 mg/dL). In addition, generalized aminoaciduria was observed. Antimitochondrial M2 antibody was positive $(141 \mathrm{U} / \mathrm{mL})$ with a high 
Table. Laboratory Test Findings.

\begin{tabular}{|c|c|c|c|c|c|c|c|c|}
\hline & $\begin{array}{l}\text { before the } \\
\text { treatment }\end{array}$ & $\begin{array}{l}\text { before } \\
\text { starting the } \\
\text { third } \\
\text { treatment }\end{array}$ & & $\begin{array}{l}\text { before the } \\
\text { treatment }\end{array}$ & $\begin{array}{c}\text { before starting } \\
\text { the third } \\
\text { treatment }\end{array}$ & & $\begin{array}{l}\text { before the } \\
\text { treatment }\end{array}$ & $\begin{array}{c}\text { before starting } \\
\text { the third } \\
\text { treatment }\end{array}$ \\
\hline White Blood Cells & $52.7 \times 10^{2} / \mu \mathrm{L}$ & $58 \times 10^{2} / \mu \mathrm{L}$ & TP & $7.1 \mathrm{~g} / \mathrm{dL}$ & $7.7 \mathrm{~g} / \mathrm{dL}$ & cryoglobulins & - & ND \\
\hline $\mathrm{Neu}$ & $47.8 \%$ & $48.6 \%$ & Alb & $4.2 \mathrm{~g} / \mathrm{dL}$ & $4.3 \mathrm{~g} / \mathrm{dL}$ & free light chain $\kappa / \lambda$ & ND & 0.75 \\
\hline Ly & $35.9 \%$ & $38.1 \%$ & BUN & $12.7 \mathrm{mg} / \mathrm{dL}$ & $14.3 \mathrm{mg} / \mathrm{dL}$ & $\mathrm{M}$ protein & - & - \\
\hline Mon & $5.5 \%$ & $5.7 \%$ & $\mathrm{Cr}$ & $0.83 \mathrm{mg} / \mathrm{dL}$ & $1.57 \mathrm{mg} / \mathrm{dL}^{*}$ & $\begin{array}{l}\text { ANA speckled } \\
\text { pattern }\end{array}$ & $1: 40 *$ & - \\
\hline Eo & $10.2 \% *$ & $6.4 \%$ & eGFR & $\begin{array}{c}57.2 \mathrm{~mL} / \\
\mathrm{min} / 1.73 \mathrm{~m}^{2 *}\end{array}$ & $\begin{array}{c}27.3 \mathrm{~mL} / \\
\mathrm{min} / 1.73 \mathrm{~m}^{2 *}\end{array}$ & $\begin{array}{l}\text { ANA cytoplasmic } \\
\text { pattern }\end{array}$ & $1: 40^{*}$ & $1: 40^{*}$ \\
\hline $\mathrm{Ba}$ & $0.6 \%$ & $1.2 \%$ & UA & $1.5 \mathrm{mg} / \mathrm{dL} *$ & $1.8 \mathrm{mg} / \mathrm{dL} *$ & SS-A Ab & $\leq 7.0 \mathrm{U} / \mathrm{mL}$ & ND \\
\hline Red Blood Cells & $417 \times 10^{4} / \mu \mathrm{L}$ & $357 \times 10^{4} / \mu \mathrm{L}$ & AST & $25 \mathrm{IU} / \mathrm{L}$ & $15 \mathrm{IU} / \mathrm{L}$ & SS-B Ab & $\leq 7.0 \mathrm{U} / \mathrm{mL}$ & ND \\
\hline $\mathrm{Hb}$ & $12.8 \mathrm{~g} / \mathrm{dL}$ & $11.4 \mathrm{~g} / \mathrm{dL} *$ & ALT & $33 \mathrm{IU} / \mathrm{L}$ & $11 \mathrm{IU} / \mathrm{L}$ & $\begin{array}{l}\text { antimitochondrial } \\
\mathrm{M} 2 \mathrm{Ab}\end{array}$ & ND & $141 \mathrm{U} / \mathrm{mL}^{*}$ \\
\hline $\mathrm{Ht}$ & $40.2 \%$ & $36.5 \%$ & ALP & 725 IU/L* & $673 \mathrm{IU} / \mathrm{L} *$ & $\mathrm{TSH}$ & $0.824 \mu \mathrm{IU} / \mathrm{mL}$ & $0.736 \mu \mathrm{IU} / \mathrm{mL}$ \\
\hline PT-INR & 0.88 & 0.95 & & ALP-3 66\% & ALP-2+3 97\% & & & \\
\hline \multirow[t]{2}{*}{ APTT } & $25.5 \mathrm{sec}$ & $27.0 \mathrm{sec}$ & T-Bil & $0.8 \mathrm{mg} / \mathrm{dL}$ & $0.7 \mathrm{mg} / \mathrm{dL}$ & Urinalysis & & \\
\hline & & & $\gamma \mathrm{GTP}$ & $25 \mathrm{IU} / \mathrm{L}$ & 13 IU/L & $\mathrm{pH}$ & $7.5^{*}$ & $8.5^{*}$ \\
\hline \multicolumn{3}{|c|}{ arterial blood gas (at rest) } & LDH & 168 IU/L & $182 \mathrm{IU} / \mathrm{L}$ & Protein & $1.4 \mathrm{~g} / \mathrm{gCr} *$ & $2.6 \mathrm{~g} / \mathrm{gCr} *$ \\
\hline $\mathrm{pH}$ & 7.323 & ND & T-Cho & $200 \mathrm{mg} / \mathrm{dL}$ & ND & alb & $29.3 \%$ & ND \\
\hline $\mathrm{PCO}_{2}$ & $39.0 \mathrm{mmHg}$ & ND & LDL-C & $95 \mathrm{mg} / \mathrm{dL}$ & $90 \mathrm{mg} / \mathrm{dL}$ & $\alpha 1$-glb & $11.0 \%$ & ND \\
\hline $\mathrm{PO}_{2}$ & $69.9 \mathrm{mmHg} *$ & ND & $\mathrm{Na}$ & $140 \mathrm{mEq} / \mathrm{L}$ & $141 \mathrm{mEq} / \mathrm{L}$ & $\alpha 2-\mathrm{glb}$ & $23.2 \%$ & ND \\
\hline $\mathrm{HCO}_{3}^{-}$ & $19.6 \mathrm{mEq} / \mathrm{L} *$ & ND & $\mathrm{K}$ & $3.7 \mathrm{mEq} / \mathrm{L}$ & $3.3 \mathrm{mEq} / \mathrm{L}^{*}$ & $\beta 2$-glb & $22.4 \%$ & ND \\
\hline $\mathrm{A}-\mathrm{aDO}{ }_{2}$ & $31.4 \mathrm{mmHg} *$ & ND & $\mathrm{CL}$ & $111 \mathrm{mEq} / \mathrm{L}^{*}$ & $108 \mathrm{mEq} / \mathrm{L}$ & $\gamma$-glb & $14.1 \%$ & ND \\
\hline \multirow[t]{2}{*}{$\mathrm{SpO}_{2}$} & $94.50 \%$ & ND & $\mathrm{Ca}$ & $8.7 \mathrm{mg} / \mathrm{dL}$ & $9.8 \mathrm{mg} / \mathrm{dL}$ & Sugar & $2+*$ & $4+*$ \\
\hline & & & $\mathrm{P}$ & $2.3 \mathrm{mg} / \mathrm{dL} *$ & $1.6 \mathrm{mg} / \mathrm{dL}^{*}$ & & & $696 \mathrm{mg} / \mathrm{dL} *$ \\
\hline HBs Ag & $0.00 \mathrm{IU} / \mathrm{mL}$ & $0.00 \mathrm{IU} / \mathrm{mL}$ & CRP & $0.01 \mathrm{mg} / \mathrm{dL}$ & $0.02 \mathrm{mg} / \mathrm{dL}$ & Red Blood Cells & $1.3 / \mathrm{HPF}$ & $1.2 / \mathrm{HPF}$ \\
\hline $\mathrm{HCV}$ Ab -II & $0.07 \mathrm{~S} / \mathrm{CO}$ & $0.05 \mathrm{~S} / \mathrm{CO}$ & GLU & $95 \mathrm{mg} / \mathrm{dL}$ & $93 \mathrm{mg} / \mathrm{dL}$ & White Blood Cells & 2.9/HPF & 2.4/HPF \\
\hline $\mathrm{HBs} \mathrm{Ab}$ & ND & $0.1 \mathrm{mIU} / \mathrm{mL}$ & HbA1c (NGSP) & $5.0 \%$ & $5.4 \%$ & Granular casts & $+*$ & - \\
\hline $\mathrm{HBc} \mathrm{Ab}$ & ND & $0.05 \mathrm{~S} / \mathrm{CO}$ & Magnesium & $2.6 \mathrm{mg} / \mathrm{dL}$ & $2.7 \mathrm{mg} / \mathrm{dL}^{*}$ & Epithelial cell casts & $t^{*}$ & - \\
\hline & & & PTH-intact & $24.3 \mathrm{pg} / \mathrm{mL}$ & $52.0 \mathrm{pg} / \mathrm{mL}$ & NAG & $9.0 \mathrm{U} / \mathrm{L}^{*}$ & $8.0 \mathrm{U} / \mathrm{L}^{*}$ \\
\hline $\begin{array}{l}\text { interferon-gamma } \\
\text { release assays }\end{array}$ & - & - & $1,25(\mathrm{OH})_{2} \mathrm{VD}_{3}$ & ND & $26.8 \mathrm{pg} / \mathrm{mL}$ & $\beta 2 \mathrm{MG}$ & $14,774 \mu \mathrm{g} / \mathrm{L}^{*}$ & $64,978 \mu \mathrm{g} / \mathrm{L} *$ \\
\hline \multirow[t]{12}{*}{ sputum culture } & $\begin{array}{l}\text { no particular } \\
\text { findings }\end{array}$ & ND & $\operatorname{IgG}$ & $1,022 \mathrm{mg} / \mathrm{dL}$ & $837 \mathrm{mg} / \mathrm{dL}^{*}$ & Bence Jones protein & - & ND \\
\hline & & & $\operatorname{Ig} \mathrm{A}$ & $262 \mathrm{mg} / \mathrm{dL}$ & $261 \mathrm{mg} / \mathrm{dL}$ & $\mathrm{Na}$ & $57 \mathrm{mEq} / \mathrm{L}$ & $56 \mathrm{mEq} / \mathrm{L}$ \\
\hline & & & $\operatorname{IgM}$ & $630 \mathrm{mg} / \mathrm{dL}^{*}$ & $637 \mathrm{mg} / \mathrm{dL}^{*}$ & $\mathrm{~K}$ & $21 \mathrm{mEq} / \mathrm{L}$ & $63.2 \mathrm{mEq} / \mathrm{L}$ \\
\hline & & & IgG4 & $14.0 \mathrm{mg} / \mathrm{dL}$ & ND & $\mathrm{CL}$ & $44 \mathrm{mEq} / \mathrm{L}$ & $31 \mathrm{mEq} / \mathrm{L}$ \\
\hline & & & $\mathrm{C} 3$ & $75 \mathrm{mg} / \mathrm{dL} *$ & $88.3 \mathrm{mg} / \mathrm{dL}^{*}$ & urine $\mathrm{Ca} / \mathrm{Cr}$ ratio & ND & $0.21 *$ \\
\hline & & & $\mathrm{C} 4$ & $18 \mathrm{mg} / \mathrm{dL}$ & $20.9 \mathrm{mg} / \mathrm{dL}$ & & & \\
\hline & & & & & & $\begin{array}{l}\mathrm{FEHCO}_{3}^{-} \\
\text {(after loading } \\
\text { bicarbonate) }\end{array}$ & ND & $8.0 \% *$ \\
\hline & & & & & & FEP & ND & $56.6 \% *$ \\
\hline & & & & & & $\% \mathrm{TRP}$ & ND & $43.4 \% *$ \\
\hline & & & & & & TmP/GFR & ND & $0.95 \mathrm{mg} / \mathrm{dL}^{*}$ \\
\hline & & & & & & FEUA & $34.1 \% *$ & $75.6 \% *$ \\
\hline & & & & & & FEK & $12 \% *$ & $105.1 \% *$ \\
\hline
\end{tabular}

Asterisks (*) indicate abnormal values.

A-aDO 2 : alveolar-arterial oxygen difference, Ab: antibody, Ag: antigen, Alb: albumin, ALP: alkaline phosphatase, ALT: alanine aminotransferase, ANA: antinuclear antibody, APTT: activated partial thromboplastin time, AST: aspartate aminotransferase, Ba: basophils, $\beta 2 \mathrm{MG}$ : beta- 2 microglobulin, BUN: blood urea nitrogen, Cr: creatinine, CRP: C-reactive protein, eGFR, estimated glomerular filtration rate, Eo: eosinophils, $\mathrm{FECHO}_{3}{ }^{-}$: fractional excretion of bicarbonate, FEK: fractional excretion of potassium, FEP: fractional excretion of phosphate, FEUA: fractional excretion of uric acid, glb: globulin, GLU: casual blood glucose, YGTP: gamma-glutamyl transpeptidase, Hb: hemoglobin, HBc: hepatitis B core, HBs: hepatitis B surface, HCV: hepatitis C virus, HIV: human immunodeficiency virus, Ht: hematocrit, Ig: immunoglobulin, LDH: lactate dehydrogenase, LDL-C: low-density lipoprotein cholesterol, Ly: lymphocytes, Mon: monocytes, NAG: N-acetyl-beta-D-glucosaminidase, ND: no data, Neu: neutrophils, NGSP: National Glycohemoglobin Standardization Program, PTH: parathyroid hormone, PT-INR: prothrombin time-international normalized ratio, $\mathrm{SpO}_{2}$ : saturation of percutaneous oxygen, T-Cho: total cholesterol, T-Bil: total-bilirubin, TP: total protein, TRP: tubular re-absorption of phosphate, TSH: thyroid-stimulating hormone, TmP/GFR: tubular maximum of phosphate, T4: thyroxine 4, UA: uric acid, 1, $25(\mathrm{OH})_{2} \mathrm{VD}_{3}$ : 1, 25- dihydroxy vitamin $\mathrm{D}_{3}$ 
a

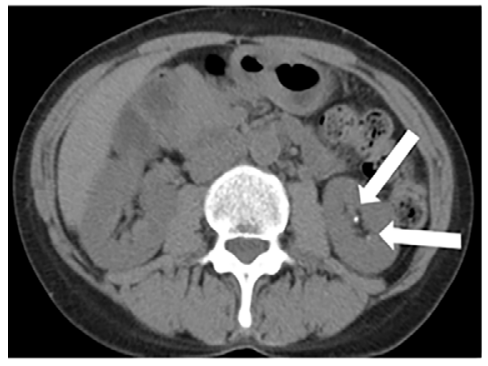

d

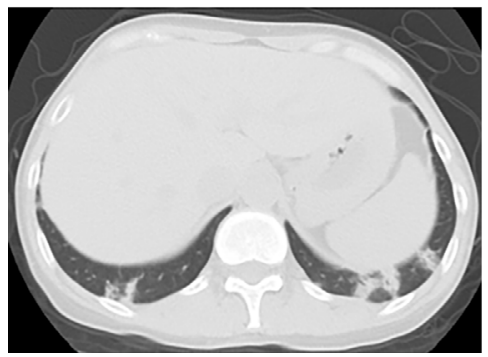

b

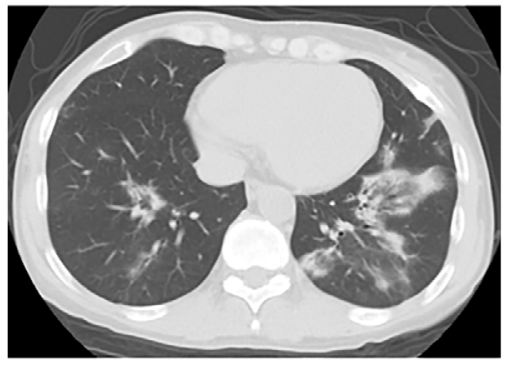

$\mathrm{e}$

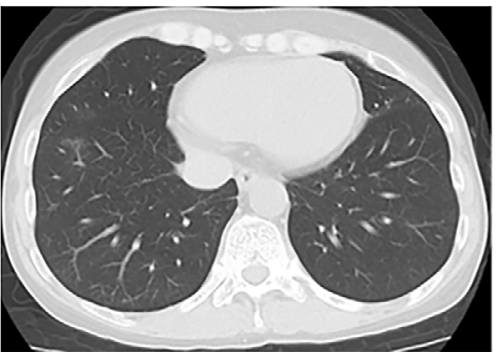

c

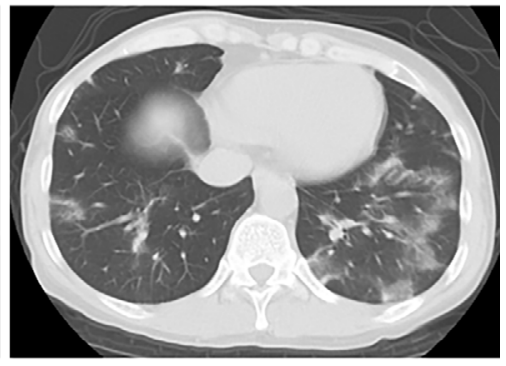

Figure 1. Computed tomography findings. (a) Abdominal computed tomography showed left kidney stones (arrows). (b, c) Chest computed tomography showed bilateral multifocal peribronchial infiltrates that mainly existed in the lower lobes. (d) Subpleural consolidations were also seen in the lower lobes. (e) Bilateral multifocal peribronchial shadows vanished after the first steroid therapy.

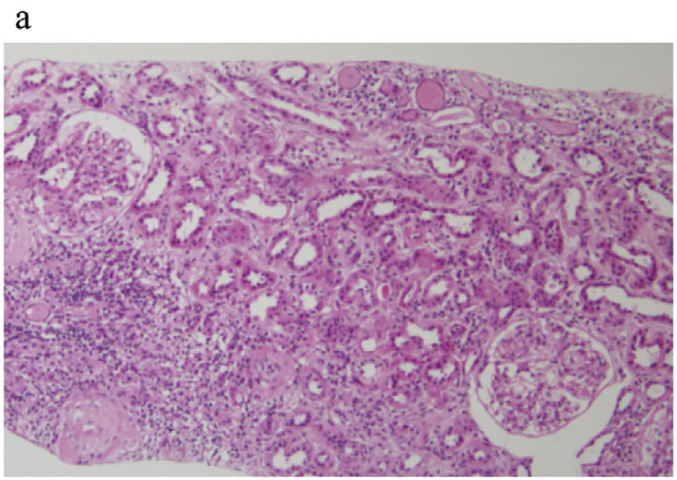

$\mathrm{b}$ $\mathrm{C}$
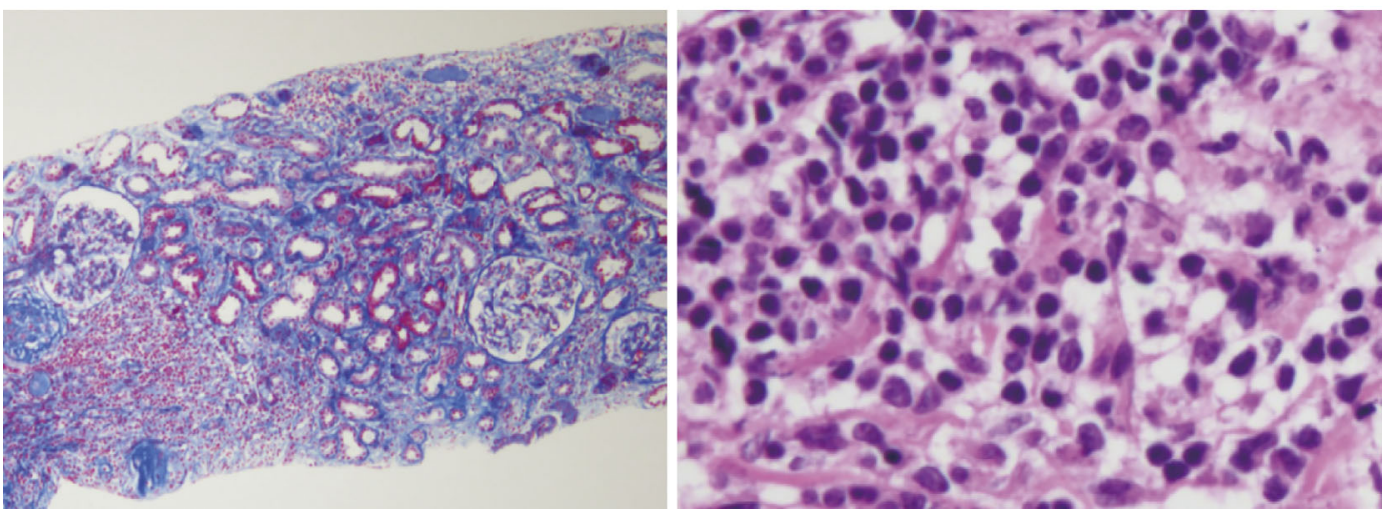

Figure 2. Histological findings in the kidney. (a, b) Light microscopy showed lymphocyte infiltration within the interstitial compartment and between tubules [a: Hematoxylin and Eosin (H\&E) staining $\times 100$, b: Azan Mallory $\times 100]$. (c) Lymphocytes and plasma cells infiltrated the interstitium (H\&E staining $\times 400$ ).

level of $\operatorname{IgM}(637 \mathrm{mg} / \mathrm{dL})$. Her liver function was normal, and abdominal ultrasonography did not show any signs of abnormality in the liver or biliary system. A liver biopsy was not conducted at her request. She might have had as- 


\section{a}

b
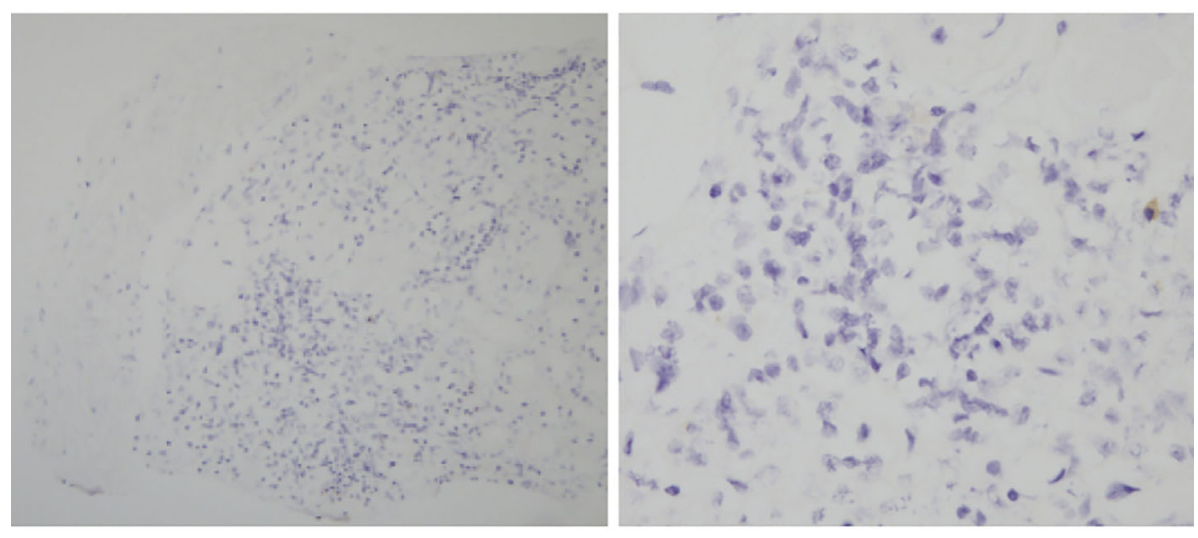

C

d
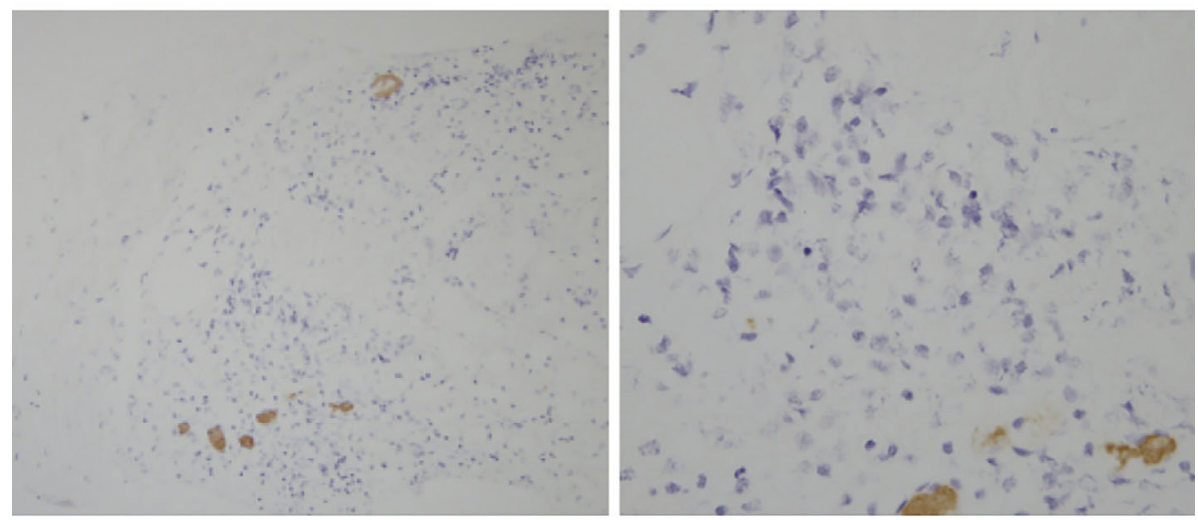

$\mathrm{e}$

$\mathrm{f}$
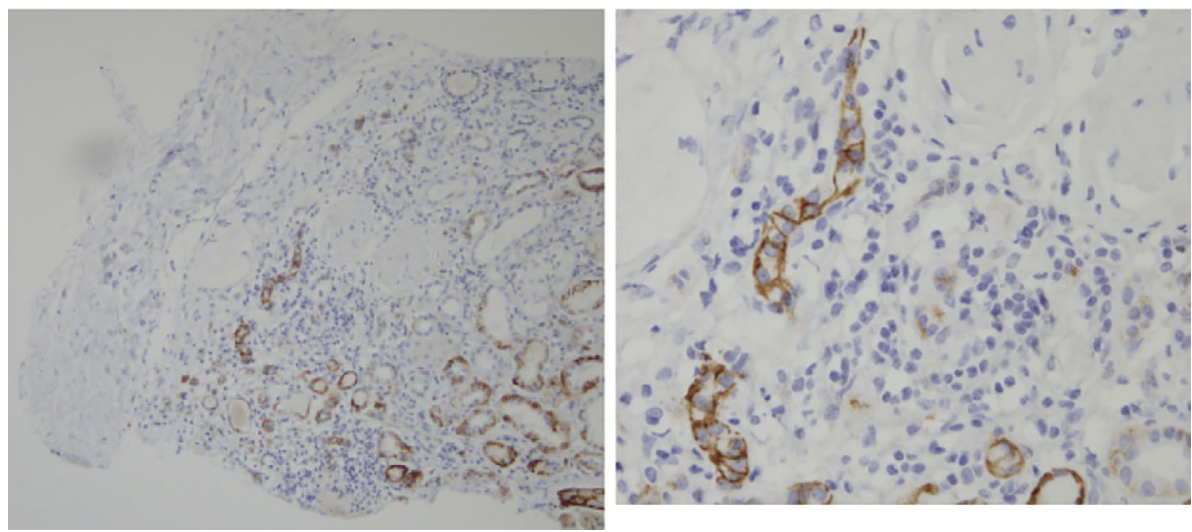

Figure 3. Histological findings in the kidney by the immunoenzyme method with formalin-fixed paraffin-embedded sections. (a, b) IgG-positive plasma cells were not detected in the interstitial compartment (IgG staining a: $\times \mathbf{1 0 0 ,} b: \times 400)$. (c, d) IgM-positive plasma cells were not seen $($ IgM staining c: $\times 100, d: \times 400) .(e, f)$ Some of the cells in the interstitium were CD138-positive (CD138 staining e: $\times 100, \mathrm{f}: \times 400)$.

ymptomatic primary biliary cholangitis but did not satisfy the criteria without a liver biopsy (11). She suffered bone pain again and needed crutches to walk. CT revealed bone fractures in the ribs, although she had no history of relevant trauma (Fig. 6a-c). A few steps of running led to left femoral neck fracture (Fig. 6d), but she did not show any signs of pulmonary involvement.

Finally, her TIN was diagnosed as TIN with antimitochondrial antibody; she started a third round of oral predni- solone therapy $(20 \mathrm{mg} /$ day) about 2 years after the second round. After a few months, her eGFR increased to $34.7 \mathrm{~mL} /$ $\min / 1.73 \mathrm{~m}^{2}$, her serum phosphorus increased to $3.9 \mathrm{mg} / \mathrm{dL}$, her ALP and U- $\beta 2 \mathrm{MG}$ decreased, and her IgM decreased to $147 \mathrm{mg} / \mathrm{dL}$. Her bone pain was relieved. After three months, she did not need crutches to walk anymore, and the dose of prednisolone was tapered. Eight months after she started the third round of prednisolone therapy, azathioprine $(75 \mathrm{mg} /$ day) was added. At this time (about eight years after the 


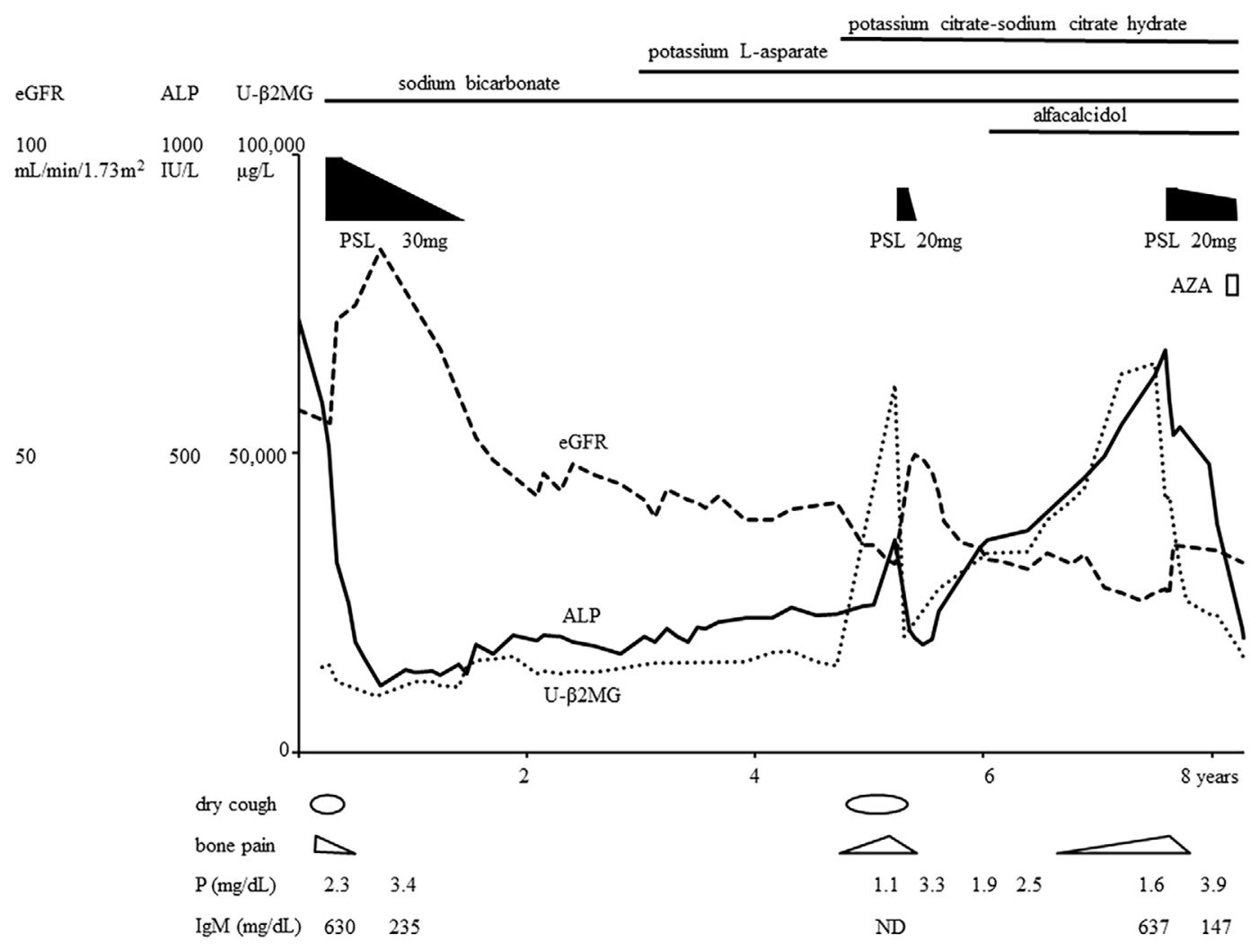

Figure 4. Clinical course. ALP: alkaline phosphatase, AZA: azathioprine, eGFR: estimated glomerular filtration rate, ND: no data, PSL: prednisolone, $U$ - $\beta 2 M G$ : urine $\beta 2$ microglobulin

a

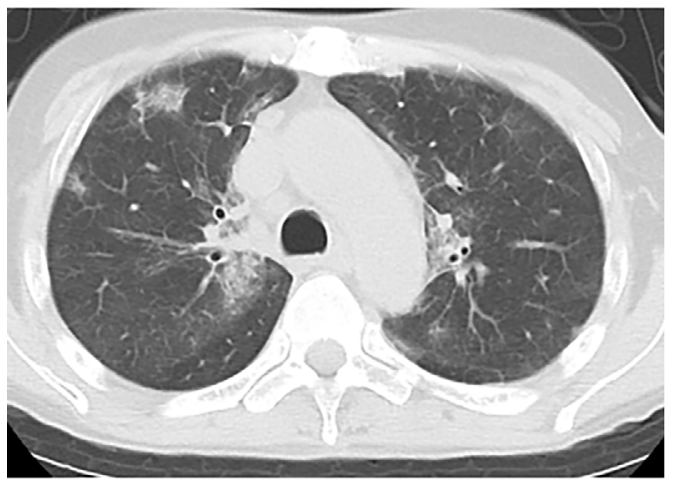

C

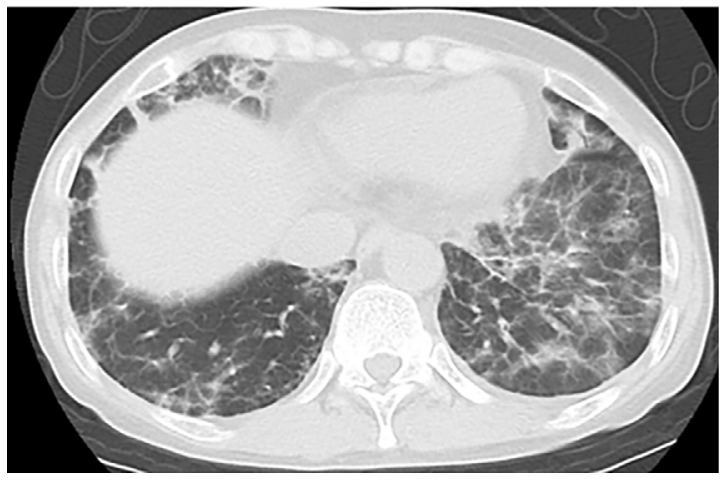

b

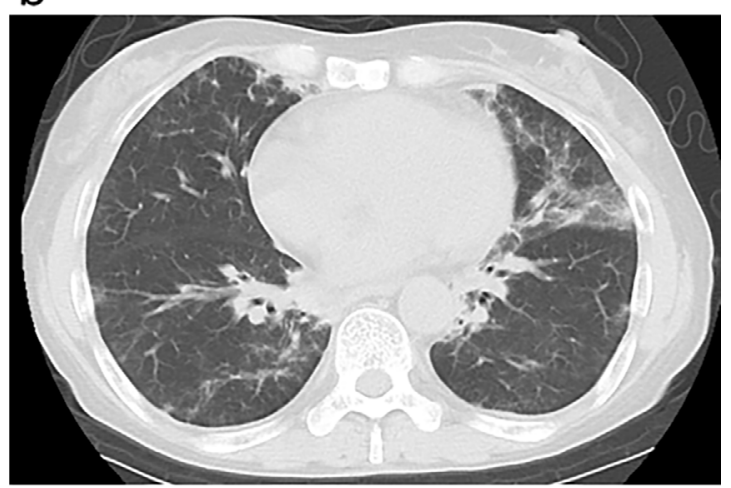

d

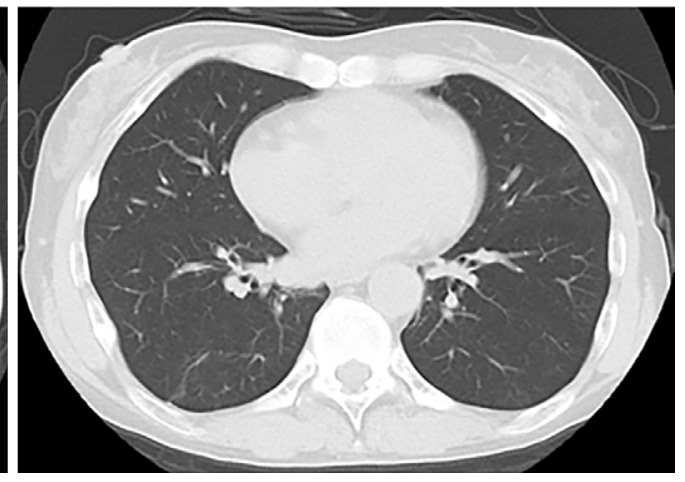

Figure 5. Recurrence of lung involvement. (a-c) Computed tomography showed bilateral multifocal reticulonodular, reticulofibrotic infiltrates with ground-glass opacification mainly in the lower lobes. (d) After the second round of steroid therapy, the bilateral shadows disappeared. 


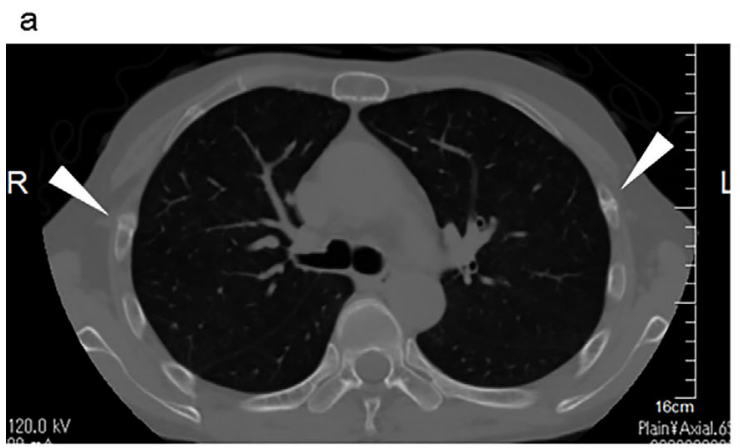

b

C

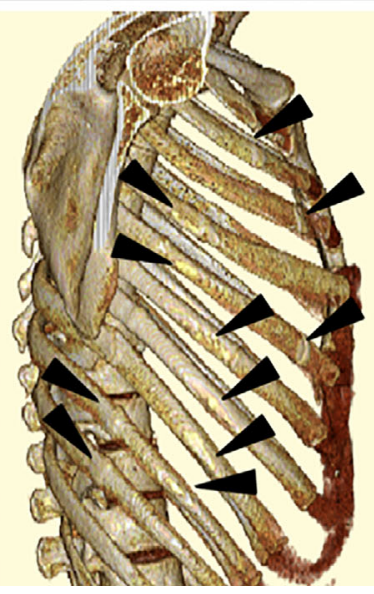

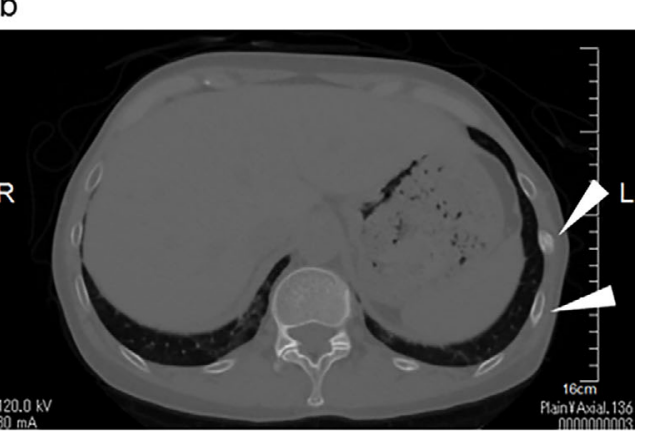

d

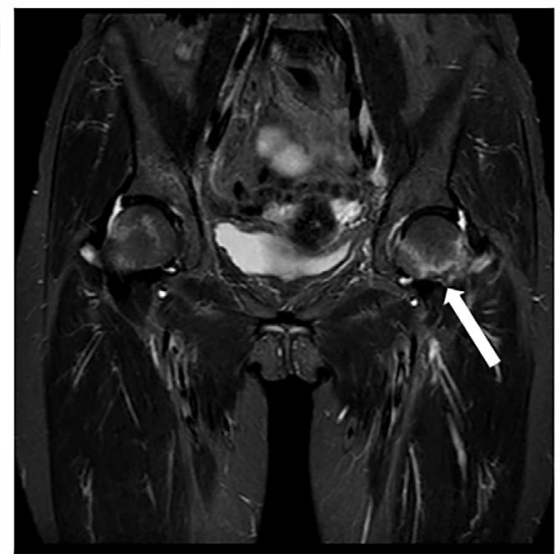

Figure 6. Bone fractures. (a-c) Computed tomography revealed bone fractures in the ribs (arrowheads). (b) Magnetic resonance imaging showed left femoral neck fracture (arrow) (short-T1 inversion recovery, turbo spin echo).

first round of prednisolone therapy), no signs of recurrence had been detected (Fig. 4).

\section{Discussion}

Proteinuria was one of the two reasons the present patient was referred to our hospital, and her urinary protein consisted largely of low-molecular-weight protein. TIN with AMAs has been reported to respond to glucocorticoids. However, some cases have relapsed after glucocorticoid therapy or did not respond to glucocorticoids at all. Macdougall et al. reported a 50-year-old woman treated with prednisolone (40 $\mathrm{mg}$ for 7 weeks, then reduced to $5 \mathrm{mg}$ for 4 weeks); her creatinine clearance recovered from 28 to 68 $\mathrm{mL} / \mathrm{min}$. After the glucocorticoid therapy was ended, the creatinine clearance decreased to $26 \mathrm{~mL} / \mathrm{min}$ (1). Lino et al. reported 2 cases of a 51- and 68-year-old woman. Both were treated with steroids $(0.5 \mathrm{mg} / \mathrm{kg} / \mathrm{day})$. In the younger case, the serum creatinine $(1.77 \mathrm{mg} / \mathrm{dL})$ slightly decreased to $1.35 \mathrm{mg} / \mathrm{dL}$ but then increased to $1.58 \mathrm{mg} / \mathrm{dL}$ after the 6month steroid therapy regimen had ended. In the older case, the serum creatinine $(1.3 \mathrm{mg} / \mathrm{dL})$ did not improve at all but increased to $2.29 \mathrm{mg} / \mathrm{dL}$ (2). The present case responded to prednisolone and relapsed twice after tapering prednisolone. We tested for AMA only after the second relapse. As in the cases described above, TIN with AMAs can relapse after glucocorticoid therapy. Therefore, when tapering prednisolone for a third time, azathioprine was added. Mycopheno- late mofetil and rituximab are other viable options, but the most suitable treatment for TIN with AMAs has not yet been established (12). To our knowledge, this is the first reported case of TIN with AMAs treated with azathioprine and glucocorticoids. We believe that the accumulation of similar cases for long periods is needed to determine the optimal initial dose of glucocorticoids, the optimal period of treatment, the need for a maintenance dose of glucocorticoids, and the effect of immunosuppressants.

TIN with IgM-positive cells is a new histologic entity with clinical features similar to the present case, such as RTA, Fanconi syndrome, high serum IgM levels and AMA positivity and one of its features is IgM-positive plasma cell (CD138-positive cell) infiltration (13-15). CD138 is an excellent marker of plasma cells $(16,17)$, but it is also expressed in some B-chronic lymphocytic leukemia (18) and in body cavity-based lymphomas (primary effusion lymphomas) (19). Our case did not show clinical aspects of either of these entities. However, IgG- and IgM-positive cells were not detected in our case. IgE-containing plasma cells in TIN were reported using immunofluorescence in a case of drug (phenobarbitone)-induced TIN (20) and in a case of TIN with polyarteritis nodosa (21); IgA plasma cell infiltration in TIN was also reported in a patient with hepatocellular carcinoma as a control (22). However, due to the anatomical pathology, including the findings of case reports, it is impossible to avoid false positive and false negative findings (23). Our IgG and $\operatorname{IgM}$ staining findings may have been due to 
technical errors, or the plasma cells in our case might contain other immunoglobulins, such as $\operatorname{IgE}$ and $\operatorname{IgA}$, rather than $\operatorname{IgG}$ and $\operatorname{IgM}$. We were unable to conclusively determine the type of immunoglobulin in those plasma cells, and our case was not diagnosed as TIN with IgM-positive plasma cells but as TIN with AMAs. The difference between TIN with IgM-positive plasma cells and TIN with AMAs is not clearly defined at present. While TIN with IgM-positive cells and TIN with AMAs do not always coincide with primary biliary cholangitis (PBC) $(3,14)$, IgM-positive plasma cell infiltraion in the liver is useful for differentiating $\mathrm{PBC}$ from autoimmune hepatitis (24). However, the usefullness of $\mathrm{IgG}$ and $\operatorname{IgM}$ staining was reported to be limited becase of the low sensitivity of IgM staining, the equivocal IgM staining, and the difficulty associated with interpreting immunostaining (25). As for the progression of TIN with those plasma cells in the kidney, serum immunoglobulin might also have some association with the progression of TIN. In our case and other cases of TIN with IgM-positive plasma cells $(13,15)$, the serum $\operatorname{IgM}$ level increases when TIN worsened. However, PBC has been reported to coexist with acqired total $\operatorname{IgG}$ deficiency (26), selective $\operatorname{IgA}$ deficiency (27), and common variable immunodeficiency, in which the serum levels of $\operatorname{IgG}, \operatorname{IgA}$, and $\operatorname{IgM}$ are decreased (28). Immunoglobulin-mediated mechanisms might not be essential, even for the progression of PBC. The underlying mechanisms and pathogenesis of plasma cells' involvement in the kidney and high serum IgM levels are not clear in TIN with AMAs/IgM-positive plasma cells.

Pulmonary involvement was another reason the present patient was referred to our hospital. Mason et al. reported five cases of fibrosing alveolitis with complete renal tubular acidosis and four cases of fibrosing alveolitis with incomplete RTA (29). Fibrosing alveolitis was a previously employed term used to describe interstitial pneumonia; autoimmune processes have reportedly been involved in the pathogenesis of some cases (30). In Mason's report, some patients showed high serum IgM levels. Furthermore, AMAs were positive in some of them, and all of them had Sjögren's syndrome and/or PBC. The renal and pulmonary abnormalities were assumed to be part of a systematic disorder capable of affecting many organs. The authors were interested in the possible association between pulmonary involvement and hyperglobulinemic RTA alone. While both Sjögren's syndrome (31) and PBC (32) can be complicated with pulmonary involvement, proximal and distal RTA are caused by TIN (33). IgM and/or AMAs might be pathophysiologically related to pulmonary involvement and TIN/RTA. The renal and pulmonary abnormalities might be part of a systematic/ autoimmune disorder capable of affecting many organs. In the present case, the TIN and pulmonary involvement seemed to take a similar clinical course, except for at the final relapse. As Mason et al. were interested in the possible association between pulmonary involvement and hyperglobulinemic RTA, the interstitial pneumonia in this case was assumed to be related to hyperglobulinemic RTA, which is one of the main features of TIN with AMAs. However, Mason et al. did not mention the coexistence of TIN in their cases. Furthermore, pulmonary involvement has not been reported in TIN with AMAs/IgM-positive plasma cells thus far (1-5, 13-15). The absence of Sjögren's syndrome, but a definite finding for PBC, TIN with AMA in this case suggested for the first time a possible association between lung involvement and TIN with AMAs. We did not analyze the inflammatory cells in the patient's spontaneous and/or induced sputum, nor did we test the levels of pulmonary surfactant proteins surfactant protein (SP)-A, SP-D, and Krebs von den Lungen (KL)-6.

In summary, we reported a case of TIN with AMA M2 antibody, high serum IgM levels, distal RTA, and Fanconi syndrome that was treated effectively with prednisolone and azathioprine. Notably, our case had pulmonary involvement. Care should be taken concerning the possibility of pulmonary involvement in patients diagnosed with TIN with AMAs. In our case, interstitial pneumonia relapsed once, and TIN relapsed twice. These findings underscore the need for a maintenance dose of glucocorticoids and immunosuppressants in cases of TIN with AMAs.

This article does not contain any studies with human participants or animals performed by any of the authors. All procedures performed in studies involving human participants were in accordance with the 1964 Declaration of Helsinki and its later amendments or comparable ethical standards.

Informed consent was obtained from all individual participants included in this study.

The authors state that they have no Conflict of Interest (COI).

\section{References}

1. Macdougall IC, Isles CG, Whitworth JA, More IA, MacSween RN. Interstitial nephritis and primary biliary cirrhosis: a new association? Clin Nephrol 27: 36-40, 1987.

2. Lino M, Binaut R, Noel LH, et al. Tubulointerstitial nephritis and Fanconi syndrome in primary biliary cirrhosis. Am J Kidney Dis 46: e41-e46, 2005.

3. Hara M, Miyazawa R, Takagi A, et al. [Case of fanconi syndrome positive for anti-M2 antibodies revealed by severe hypokalemia and multiple bone fracture]. Nihon Jinzo Gakkai Shi 53: 719-725, 2011 (in Japanese, Abstract in English).

4. Saeki T, Nakajima A, Ito T, et al. Tubulointerstitial nephritis and Fanconi syndrome in a patient with primary Sjögren's syndrome accompanied by antimitochondrial antibodies: a case report and review of the literature. Mod Rheumatol 28: 897-900, 2018.

5. Morita M, Yamaguchi Y, Masuyama S, et al. Anti-mitochondria antibody-related tubulointerstitial nephritis accompanied by severe hypokalemic paralysis. CEN Case Rep 8: 119-124, 2019.

6. Vitali C, Bombardieri S, Jonsson R, et al. Classification criteria for Sjögren's syndrome: a revised version of the European criteria proposed by the American-European Consensus Group. Ann Rheum Dis 61: 554-558, 2002.

7. Fujibayashi T, Sugai S, Miyasaka N, et al. Revised Japanese criteria for Sjögren's syndrome (1999): availability and validity. Mod 
Rheumatol 14: 425-434, 2004.

8. Shiboski CH, Shiboski SC, Seror R, et al. 2016 American College of Rheumatology/European League Against Rheumatism Classification Criteria for Primary Sjögren's syndrome: a consensus and data-driven methodology involving three international patient cohorts. Arthritis Rheumatol 69: 35-45, 2017.

9. Rodriguez Soriano J. Renal tubular acidosis: the clinical entity. J Am Soc Nephrol 13: 2160-2170, 2002.

10. Haque SK, Ariceta G, Batlle D. Proximal renal tubular acidosis: a not so rare disorder of multiple etiologies. Nephrol Dial Transplant 27: 4273-4287, 2012.

11. Bowlus CL, Gershwin ME. The diagnosis of primary biliary cirrhosis. Autoimmun Rev 13: 441-444, 2014.

12. Joyce E, Glasner P, Ranganathan S, Swiatecka-Urban A. Tubulointerstitial nephritis: diagnosis, treatment, and monitoring. Pediatr Nephrol 32: 577-587, 2017.

13. Takahashi N, Kimura H, Kawajiri Y, et al. Tubulointerstitial nephritis with IgM-positive plasmacytoid large lymphocyte infiltration in a patient with primary biliary cirrhosis and Sjogren's syndrome. Clin Nephrol 74: 74-80, 2010.

14. Takahashi N, Saeki T, Komatsuda A, et al. Tubulointerstitial nephritis with IgM-positive plasma cells. J Am Soc Nephrol 28: 3688-3698, 2017.

15. Mizoguchi S, Katayama K, Murata T, et al. IgM-positive tubulointerstitial nephritis associated with asymptomatic primary biliary cirrhosis. Kidney Int Rep 3: 1004-1009, 2018.

16. Kishimoto $\mathrm{T}$; International Workshop and Conference on Human Leucocyte Differentiation Antigens. B-cell antigens. In: Leucocyte Typing VI. Garland Publishing, New York, 1997: 249-252.

17. Jourdan M, Ferlin M, Legouffe E, et al. The myeloma cell antigen syndecan-1 is lost by apoptotic myeloma cells. $\mathrm{Br} \mathrm{J}$ Haematol 100: 637-646, 1998.

18. Kopper L, Sebestyén A, Gallai M, Kovalszky I. Syndecan-1 - A new piece in B-cell puzzle. Pathol Oncol Res 3: 183-191, 1997.

19. Drexler HG, Uphoff CC, Gaidano G, Carbone A. Lymphoma cell lines: in vitro models for the study of HHV-8+ primary effusion lymphomas (body cavity-based lymphomas). Leukemia 12: 1507 1517, 1998.

20. Faarup P, Christensen E. Letter: IgE-containing plasma cells in acute tubulo-interstitial nephropathy. Lancet 2: 718, 1974.

21. Dixon AJ, Winearls CG, Dunnill MS. Interstitial nephritis. J Clin Pathol 34: 616-624, 1981.

22. Rowley AH, Shulman ST, Mask CA, et al. IgA plasma cell infiltration of proximal respiratory tract, pancreas, kidney, and coro- nary artery in acute Kawasaki disease. J Infec Dis 182: 11831191, 2000.

23. Crawford JM. Original research in pathology: judgment, or evidence-based medicine? Lab Invest 87: 104-114, 2007.

24. Daniels JA, Torbenson M, Anders RA, Boitnott JK. Immunostaining of plasma cells in primary biliary cirrhosis. Am J Clin Pathol 131: 243-249, 2009.

25. Lee H, Stapp RT, Ormsby AH, Shah VV. The usefulness of IgG and IgM immunostaining of periportal inflammatory cells (plasma cells and lymphocytes) for the distinction of autoimmune hepatitis and primary biliary cirrhosis and their staining pattern in autoimmune hepatitis-primary biliary cirrhosis overlap syndrome. Am J Clin Pathol 133: 430-437, 2010.

26. Take H, Kubota K, Tamura K, Kurabayashi H, Tamura J, Shirakura T. Acquired total immunoglobulin G deficiency in a patient with primary biliary cirrhosis. J Intern Med 238: 289-292, 1995.

27. James SP, Jones EA, Schafer DF, Hoofnagle JH, Varma RR, Strober W. Selective immunoglobulin A deficiency associated with primary biliary cirrhosis in a family with liver disease. Gastroenterology 90: 283-288, 1986.

28. Kawaguchi T, Tanaka T, Hashiguchi M, et al. Decreased serum levels of immunoglobulin $\mathrm{A}$, immunoglobulin $\mathrm{M}$ and immunoglobulin $G$ in a patient with primary biliary cirrhosis: a case report. Hepatol Res 44: E261-E266, 2014.

29. Mason AM, McIllmurray MB, Golding PL, Hughes DT. Fibrosing alveolitis associated with renal tubular acidosis. Br Med J 4: 596599, 1970.

30. Thomas P. Fibrosing alveolitis. Can Med Assoc J 119: 1211-1216, 1978.

31. Flament T, Bigot A, Chaigne $B$, Henique $H$, Diot $E$, Marchand-Adam S. Pulmonary manifestations of Sjögren's syndrome. Eur Respir Rev 25: 110-123, 2016.

32. Koksal D, Koksal AS, Gurakar A. Pulmonary manifestations among patients with primary biliary cirrhosis. J Clin Transl Hepatol 4: 258-262, 2016.

33. Mustaqeem R, Arif A. Renal tubular acidosis. In: StatPearls. Treasure Island (FL), 2019.

The Internal Medicine is an Open Access journal distributed under the Creative Commons Attribution-NonCommercial-NoDerivatives 4.0 International License. To view the details of this license, please visit (https://creativecommons.org/licenses/ by-nc-nd/4.0/).

(C) 2020 The Japanese Society of Internal Medicine Intern Med 59: 1179-1187, 2020 